Article

\title{
Increased Activity of 5-Enolpyruvylshikimate-3-phosphate Synthase (EPSPS) Enzyme Describe the Natural Tolerance of Vulpia myuros to Glyphosate in Comparison with Apera spica-venti
}

\author{
Muhammad Javaid Akhter, Solvejg Kopp Mathiassen (D, Zelalem Eshetu Bekalu, Henrik Brinch-Pedersen ${ }^{D}$ \\ and Per Kudsk * (D) \\ Research Centre Flakkebjerg, Department of Agroecology, Aarhus University, DK-4200 Slagelse, Denmark; \\ javedakhter8864@gmail.com (M.J.A.); sma@agro.au.dk (S.K.M.); zelaleme.bekalu@agro.au.dk (Z.E.B.); \\ hbp@agro.au.dk (H.B.-P.) \\ * Correspondence: per.kudsk@agro.au.dk
}

check for updates

Citation: Akhter, M.J.; Mathiassen S.K.; Bekalu, Z.E.; Brinch-Pedersen, H.; Kudsk, P. Increased Activity of 5-Enolpyruvylshikimate-3-phosphate Synthase (EPSPS) Enzyme Describe the Natural Tolerance of Vulpia myuros to Glyphosate in Comparison with Apera spica-venti. Agriculture 2021, 11, 725. https://doi.org/ 10.3390 /agriculture11080725

Academic Editor: Anna Andolfi

Received: 3 June 2021

Accepted: 26 July 2021

Published: 30 July 2021

Publisher's Note: MDPI stays neutral with regard to jurisdictional claims in published maps and institutional affiliations.

Copyright: (c) 2021 by the authors. Licensee MDPI, Basel, Switzerland. This article is an open access article distributed under the terms and conditions of the Creative Commons Attribution (CC BY) license (https:/ / creativecommons.org/licenses/by/ $4.0 /)$.
Abstract: Rattail fescue (Vulpia myuros (L.) C.C. Gmel.) is a self-pollinating winter annual grassy weed of winter annual crops. The problems with V. myuros are mostly associated with no-till cropping systems where glyphosate application before sowing or emergence of the crop is the most important control measure. Ineffective $V$. myuros control has been reported following glyphosate applications. Experiments were performed to study the effectiveness of glyphosate on V. myuros, and determine the causes of the lower performance of glyphosate on $V$. myuros compared to other grass weeds. Estimated $\mathrm{GR}_{50}$ values demonstrated that $V$. myuros was less susceptible to glyphosate than Apera spica-venti regardless of the growth stage. Within each species, glyphosate efficacy at different growth stages was closely related to spray retention. However, the low susceptibility to glyphosate in $V$. myuros was not caused by lower retention as previously suggested. A significantly lower shikimic acid accumulation in $V$. myuros compared to A. spica-venti was associated with a higher activity of the EPSPS enzyme in $V$. myuros. Nevertheless, the relative responses in EPSPS activity to different glyphosate concentrations were similar in the two grass species, which indicate that EPSPS from $V$. myuros is as susceptible to glyphosate as EPSPS from A. spica-venti suggesting no alternation in the binding site of EPSPS. The results from the current study indicate that $V$. myuros is less susceptible to glyphosate compared to A. spica-venti, and the low susceptibility of V. myuros is caused by an increased EPSPS enzyme activity.

Keywords: chemical control; spray retention; narrow leaves; tolerance

\section{Introduction}

Rattail fescue (Vulpia myuros (L.) C.C. Gmel.) is considered a problematic weed in Northern European countries [1]. Since first reported in Denmark in 1990, areas infested with V. myuros have significantly increased [2]. Initially, V. myuros was primarily found in grass seed crops, in particular red fescue; however, with increasing adoption of no-till practices and repeated cropping of winter cereals, $V$. myuros is now considered a common weed in winter cereal crops as well [3,4].

Vulpia myuros is a winter annual grass weed with a life cycle very similar to winter wheat [5]. Vulpia myuros is a prolific seed producer and can form a large seed-bank in a single season under poor weed management scenarios [6]. A recent study reported up to $50 \%$ winter wheat yield losses at a density of $405 \mathrm{~V}$. myuros plants $\mathrm{m}^{-2}$ [7]. V. myuros has a shallow root system rendering it sensitive to soil disturbance. Furthermore, it has short seed-longevity in soil and persist longer in no-till cropping systems where seeds remain on the soil surface [8]. With the wide adoption of no-till practices, glyphosate has become a widely used herbicide for pre-plant and -emergence weed control [9]. However, V. myuros 
control with glyphosate is erratic compared to other winter annual grasses [4]. The narrow and linear leaf blades of $V$. myuros constitute a relatively small target area, and that has been suggested as a reason for the poor post-emergence herbicides performance [10,11].

Glyphosate blocks the 5-enolpyruvylshikimate-3 phosphate synthase (EPSPS, EC 2.5.1.19) enzyme. The EPSPS is the sixth enzyme in the shikimic pathway, and essential in the synthesis of three essential aromatic amino acids: phenylalanine, tyrosine, and tryptophan [12]. The inhibition of EPSPS leads to accumulation of shikimic acid, which can be measured to determine glyphosate effectiveness on plants [13]. There are two types of glyphosate resistance reported, target-site and non-target site-based. Target-site resistance is endowed by mutations conferring alterations in the amino acids, which prevents glyphosate from binding the target enzyme [14], or by the amplification of target EPSPS genes [15]. Non-target site resistance is associated with limited uptake or translocation, enhanced glyphosate metabolism or increased vacuolar glyphosate sequestration [16]. There are no reports of resistance in V. myuros to glyphosate but tolerance to ACCase and ALS inhibitors is well-known [17]. According to the international weed science society of America [18] herbicide resistance "is the inherited ability of a plant to survive and reproduce following exposure to a dose of herbicide normally lethal to the wild type"; and herbicide tolerance is "the inherent ability of a species to survive and reproduce after herbicide treatment. This implies that there was no selection or genetic manipulation to make the plant tolerant; it is naturally tolerant".

It is imperative to understand whether the lower efficacy of glyphosate against $V$. myuros is caused by a low spray deposition that could possibly be overcome by changing application parameters, such as spray volume or inclusion of adjuvants $[4,10,19]$, or whether is it due to an inherent higher tolerance of $V$. myuros compared with other grass weeds. Moreover, previous studies suggested that $V$. myuros can tolerate the recommended rates of glyphosate better than other grass weed species, such as A. spica-venti, but there is no information on the level of tolerance in $V$. myuros against glyphosate $[4,11,20]$. Thus, the objective of the current study was to examine the level and cause(s) of the lower performance of glyphosate on $V$. myuros. Apera spica-venti, one of the most problematic grass weeds in winter wheat production systems in Europe [7], was included in the study as a susceptible reference species.

\section{Material and Method}

\subsection{Seed Source}

In the summer of 2017, V. myuros seeds were collected from non-agricultural areas at Flakkebjerg, Denmark $\left(55.3^{\circ} \mathrm{N}, 11.4^{\circ} \mathrm{E}\right)$, where there was no known history of herbicide application. Seeds of susceptible $A$. spica-venti populations originating from six locations across Denmark were mixed to form a meta-population [21].

\subsection{Dose-Response and Spray Retention Study}

\subsubsection{Dose-Response Study}

Twenty seeds of $V$. myuros and A. spica-venti were planted in 1-L pots, filled with potting mixture containing soil, peat and sand (2:1:1 by weight). Pots were placed in an unheated glasshouse or on outdoor tables depending on the season in which the experiment was conducted. Groups of pots were sown on different dates to ensure that different growth stages could be sprayed simultaneously. After seedling emergence, plant numbers per pot were thinned to a pre-set number (8 plants per pot). Plants were treated with glyphosate (Roundup Bio, 360 g/L, Monsanto Crop Sciences, Hellerup, Denmark) rates ranging from 11.3 to $720 \mathrm{~g} \mathrm{ha}^{-1}$ using a spray cabinet equipped with a boom and two flat-fan nozzle (HARDI ISO F-110-02). The nozzles were operated at a pressure of three bars and velocity of $5.2 \mathrm{~km} \mathrm{~h}^{-1}$ delivering a spray volume of a $152 \mathrm{~L} /$ ha. The dose-response study was repeated three times, plants were sprayed at different plant growth stages in three repeats (Table 1). Experiment 1 was sprayed on 24-01-2019 at growth stages BBCH 11, BBCH 13 and BBCH 21, Experiment 2 was sprayed on 25-04-2019 at BBCH 22, BBCH 23 and BBCH 24, and Experiment 3 on 17-06-2019 at BBCH 22, BBCH 26 and BBCH 29. After spraying, the 
pots were placed either in an unheated glasshouse (Experiments 1 and 2) or outdoors (Experiment 3). Each experiment was performed with three replications per treatment plus six untreated controls using a complete randomized design. Dry and fresh foliage weights were recorded 4 to 5 weeks after herbicide treatment.

Table 1. Set-up of the different experiments carried out to examine the level and cause(s) of the lower performance of glyphosate on $V$. myuros.

\begin{tabular}{|c|c|c|c|}
\hline Study & Experiment & Treatment (Glyphosate Doses; Growth Stage (BBCH)) & Environment \\
\hline \multirow[t]{3}{*}{ Dose-response } & Experiment 1 & $\begin{array}{l}\text { Glyphosate rate ranging from } 11.3 \text { to } 720 \mathrm{~g} \mathrm{ha}^{-1} \\
\text { BBCH 11, BBCH 13, BBCH } 21\end{array}$ & Unheated glasshouse \\
\hline & Experiment 2 & $\begin{array}{l}\text { Glyphosate rate ranging from } 11.3 \text { to } 720 \mathrm{~g} \mathrm{ha}^{-1} \text {; } \\
\text { BBCH 22, BBCH 23, BBCH } 24\end{array}$ & Unheated glasshouse \\
\hline & Experiment 3 & $\begin{array}{l}\text { Glyphosate rate ranging from } 11.3 \text { to } 720 \mathrm{~g} \mathrm{ha}^{-1} \text {; } \\
\text { BВCH 22, BBCH 26, BBCH } 29\end{array}$ & $\begin{array}{l}\text { Outdoor under natural } \\
\text { conditions }\end{array}$ \\
\hline \multirow[t]{3}{*}{ Spray retention } & Experiment 1 & $\begin{array}{l}\text { Glyphosate rate at } 90 \mathrm{~g} \mathrm{ha}^{-1} \text { in mixture with fluorescent } \\
\text { dye at a concentration of } 200 \mathrm{~g} \mathrm{ha}^{-1} ; \mathrm{BBCH} 11, \mathrm{BBCH} 13, \\
\qquad \mathrm{BBCH} 21\end{array}$ & $\begin{array}{l}\text { Unheated glasshouse, } \\
\text { Laboratory }\end{array}$ \\
\hline & Experiment 2 & $\begin{array}{l}\text { Glyphosate rate at } 90 \mathrm{~g} \mathrm{ha}^{-1} \text { in mixture with fluorescent } \\
\text { dye at a concentration of } 200 \mathrm{~g} \mathrm{ha}^{-1} ; \mathrm{BBCH} 11, \mathrm{BBCH} 13, \\
\qquad \mathrm{BBCH} 21\end{array}$ & $\begin{array}{l}\text { Unheated glasshouse, } \\
\text { Laboratory }\end{array}$ \\
\hline & Experiment 3 & $\begin{array}{l}\text { Glyphosate rate at } 90 \mathrm{~g} \mathrm{ha}^{-1} \text { in mixture with fluorescent } \\
\text { dye at a concentration of } 200 \mathrm{~g} \mathrm{ha}^{-1} ; \mathrm{BBCH} 22, \mathrm{BBCH} 23, \\
\qquad \mathrm{BBCH} 24\end{array}$ & $\begin{array}{l}\text { Outdoor under natural } \\
\text { conditions, Laboratory }\end{array}$ \\
\hline $\begin{array}{l}\text { Whole plant shikimic } \\
\text { acid accumulation }\end{array}$ & & Glyphosate rate at $210 \mathrm{~g} \mathrm{ha}^{-1}$ and $420 \mathrm{~g} \mathrm{ha}^{-1}$; BBCH 23 & Laboratory \\
\hline $\begin{array}{l}\text { Accumulation of shikimic } \\
\text { acid in excised leaves }\end{array}$ & & $\begin{array}{l}\text { Glyphosate rate ranging from } 0 \text { to } 600 \mu \mathrm{M} \text {; BBCH } 23 \text { to } \\
\qquad \text { BBCH } 25\end{array}$ & Laboratory \\
\hline EPSPS enzyme sensitivity & & Glyphosate rate ranging from 0 to $1000 \mu \mathrm{M}$; BBCH 23 & Laboratory \\
\hline
\end{tabular}

\subsubsection{Spray Retention Assay}

Spray retention was measured at three different growth stages using similar experimental conditions as for the dose-response study. Spray retention study was repeated three times. As plants were sprayed at different plant growth stages and under different environment in three repeats, therefore, to make the interpretations of results straightforward terms Experiments 1-3 will be referred to as three runs of the study (Table 1). Two experiments (Experiments 1 and 2) were conducted on the plants grown in the unheated glasshouse and one (Experiment 3) on outdoor grown plants. Experiment 1 was performed as a part of dose-response Experiment 1, while Experiments 2 and 3 were performed as separate experiments. In Experiments 1 and 2, plants were sprayed at $\mathrm{BBCH} 11, \mathrm{BBCH} 13$, $\mathrm{BBCH}$ 21. In Experiment 3, plants were sprayed at $\mathrm{BBCH} 22, \mathrm{BBCH} 23, \mathrm{BBCH} 24$. The spray solution consisted of $90 \mathrm{~g} \mathrm{ha}^{-1}$ glyphosate in mixture with the fluorescent dye brilliant sulfoflavin at a concentration of $200 \mathrm{~g} \mathrm{ha}^{-1}$. Following spray application, five plants of each plant species were cut at soil level and washed in glass bottles containing $50 \mathrm{~mL}$ Milli $\mathrm{Q}$ water $+0.2 \%$ non-ionic surfactant (Contact, AgroDan, Brabrand, Denmark) and shaken well. A representative sample of the solution was taken for analysis. Within $12 \mathrm{~h}$, post treatment the amount of dye in repetitive samples was measured using a luminescence spectrometer (Perkin Elmer model LS50B). The samples were excited at $420 \mathrm{~nm}$ and after excitation emission was measured at $518 \mathrm{~nm}$. The actual amount of deposition on the plants was calculated from a standard curve showing the response of concentrations from 3 to $800 \mu \mathrm{g}$ per liter of the dye. The equation for the standard curve was linear with $R^{2}$ of 0.99 . Herbicide treated plant samples (sprayed with glyphosate without the fluorescent dye) and untreated plant samples (not sprayed but washed with demineralized water) were also included for comparison. The leaf area of plant samples was measured using a 
Licor 3100 area meter and was used for the calculation of per unit tracer deposition. The experiment included 10 replicates per treatment.

\subsection{Shikimic Acid Accumulation Assays}

\subsubsection{Whole Plant Shikimic Acid Accumulation}

V. myuros and A. spica-venti plants at $\mathrm{BBCH} 23$ were treated with glyphosate at the rate of $210 \mathrm{~g}_{\text {ae ha }}{ }^{-1}$ and $420 \mathrm{~g}$ ae ha ${ }^{-1}$ (Table 1). Application method was the same used in the dose-response experiment. Plant material was harvested 24, 48, 72, and $96 \mathrm{~h}$ after treatment, and stored in liquid nitrogen at $-20{ }^{\circ} \mathrm{C}$ until further analysis. Accumulation of shikimic acid was measured using a method described by Singh and Shaner [22]. A total of $450 \mathrm{~mL} \mathrm{HCl}(0.25 \mathrm{M})$ was added to $150 \mathrm{mg}$ of plant tissue in a $2 \mathrm{~mL}$ Eppendorf tube. The plant material in liquid nitrogen was ground with glass beads using a FastPrep instrument (FastPrep ${ }^{\circledR}$ FP120, Thermo Savant, CA, USA). Samples were then gently vortexed and centrifuged at $10,606 \times g$ for fifteen minutes at $4{ }^{\circ} \mathrm{C}$. Twenty $\mu \mathrm{L}$ of the supernatant was mixed with $0.5 \mathrm{~mL}$ of periodic acid $(1 \%)$ and incubated at room temperature for $3 \mathrm{~h}$. Then, $0.5 \mathrm{~mL}$ of $1 \mathrm{M} \mathrm{NaOH}$ and $0.3 \mathrm{~mL}$ of $0.1 \mathrm{M}$ glycine were added by pipette to the solution. Spectrophotometric reading of $200 \mu \mathrm{L}$ samples was performed at $380 \mathrm{~nm}$ using a 96 well plate (Epoch, BioTek, Winooski, VT, USA). Six replications were used for each glyphosate concentration and species. Plant morphology for V. myuros and A. spica-venti differs [5], which could affect spray deposition. Thus, to account for differences in spray deposition on the two species, herbicide spray deposition was determined at the same growth stage that was used to study shikimic acid accumulation, using the method described above. Results were presented as $\mu \mathrm{mol}$ of shikimate per $\mu \mathrm{g}$ glyphosate per $\mathrm{g}$ of fresh weight per $\mathrm{cm}^{2}$.

\subsubsection{Accumulation of Shikimic Acid in Excised Leaves}

Six leaf segments of $5 \mathrm{~cm}$ length were harvested from the youngest fully expanded leaves of V. myuros and A. spica-venti plants at $\mathrm{BBCH} 23$ to $\mathrm{BBCH} 25$. Fifty $\mathrm{Mg}$ of fresh plant material was transferred into a $2 \mathrm{~mL}$ Eppendorf tube containing $1 \mathrm{mM} \mathrm{NH}_{4} \mathrm{H}_{2} \mathrm{PO}_{4}$ ( $\mathrm{pH}$ 4.4). Glyphosate was added to the Eppendorf tubes at the range of 0, 0.1, 0.5, 2, 5, $10,100,200,400,500$ and $600 \mu \mathrm{M}$ (Table 1). Samples were incubated in a growth chamber for $24 \mathrm{~h}$ at $24 / 16^{\circ} \mathrm{C}$ day/night with $16 \mathrm{~h}$ photoperiod with photosynthetic photon Flux density of $850 \mu \mathrm{mol} \mathrm{m}{ }^{-2} \mathrm{~s}^{-1}$. After $24 \mathrm{~h}$ of incubation, the Eppendorf tubes were kept at $-20{ }^{\circ} \mathrm{C}$ until analysis.

Prior to analysis Eppendorf tubes were thawed at $60^{\circ} \mathrm{C}$ for $30 \mathrm{~min}$. Then $250 \mu \mathrm{L}$ of $1.25 \mathrm{~N} \mathrm{HCl}$ was added, and incubated at $60^{\circ} \mathrm{C}$ for fifteen minutes. Thereafter, a $125 \mu \mathrm{L}$ aliquot from each Eppendorf tube was transferred into a $2 \mathrm{~mL}$ Eppendorf tube, and mixed with $500 \mu \mathrm{L}$ of periodic acid and sodium metaperiodate $(0.25 \% w / v)$. Following the incubation at room temperature for $90-\mathrm{min}, 500 \mu \mathrm{L}$ of $0.6 \mathrm{~N}$ sodium hydroxide, and $0.22 \mathrm{M}$ sodium sulfite were added to the reaction mixture. The absorbance of samples was measured using a spectrophotometer (Epoch, BioTek, Winooski, VT, USA) at $380 \mathrm{~nm}$. A 96 well plate was used for analysis using $200 \mu \mathrm{L}$ of each sample. The experiment was performed in three replicates per species and was repeated twice.

\subsection{EPSPS Enzyme Sensitivity}

$V$. myuros and A. spica-venti plants were established in 1-L pots in an unheated glasshouse. Five $\mathrm{g}$ of plant material was collected from the two youngest fully expanded leaves from V. myuros and A. spica-venti plants at the three-tillering stage (BBCH 23) (Table 1). EPSPS enzyme extraction was conducted using the method described by Sammons and Gaines [14]. Five g of plant material was grounded to a fine powder by pestle and chilled mortar using liquid nitrogen. The powdered plant material was transferred to tubes containing $100 \mathrm{~mL}$ cold extraction buffer (100 mM MOPS, $5 \mathrm{mM}$ EDTA, 10\% glycerol, $50 \mathrm{mM} \mathrm{KCl}$, and $0.5 \mathrm{mM}$ benzamidine), $70 \mu \mathrm{L}$ of fresh $\beta$-mercaptoethanol, and $1 \%$ in polyvinylpolypyrrolidone. Tubes containing samples were continuously stirred and then centrifuged for $40 \mathrm{~min}(18,000 \times g)$ at $4{ }^{\circ} \mathrm{C}$. Thereafter, supernatants were decanted into a 
beaker through a cheesecloth. Ammonium sulfate $\left(\left(\mathrm{NH}_{4}\right)_{2} \mathrm{SO}_{4}\right)$ was slowly added to the solution to obtain $45 \%(w / v)$ concentration by constant stirring for $30 \mathrm{~min}$ and centrifuging at $20,000 \times g$ and $4{ }^{\circ} \mathrm{C}$ for $30 \mathrm{~min}$. The ammonium sulfate precipitation step was repeated using $80 \%(w / v)\left(\mathrm{NH}_{4}\right)_{2} \mathrm{SO}_{4}$. The extract was precipitated with gentle stirring, and the precipitate was then collected with centrifugation $\left(20,000 \times g\right.$, at $4{ }^{\circ} \mathrm{C}$ for $\left.30 \mathrm{~min}\right)$. Pellets were dissolved in $3 \mathrm{~mL}$ of extraction buffer and dialyzed overnight in $2 \mathrm{~L}$ of dialysis buffer by $30 \mathrm{~mm}, 1000-\mathrm{MWC}$ dialysis tubing at $4{ }^{\circ} \mathrm{C}$ on stir plate.

The activity of EPSPS from V. myuros and A. spica-venti plants was determined using the protocol described by Dayan et al. [13] with on EnzCheckQR phosphate assay Kit (Invitrogen, Carlsbad, CA, USA). The specific activity of EPSPS was determined in the absence and presence of glyphosate. To determine the inhibition of EPSPS activity, the following glyphosate concentrations were used: $0,0.1,10,100,1000 \mu \mathrm{M}$ (Table 1 ). The assay buffer contained $1 \mathrm{mM}$ of $\mathrm{MgCl}_{2}, 100 \mathrm{mM}$ of MOPS, $10 \%$ glycerol, $2 \mathrm{mM}$ sodium molybdate, and $200 \mathrm{mM}$ of NaF. The assay was performed in three replicates for each species, and experiments were repeated twice. The enzyme activity was calculated to measure the phosphate amount ( $\mu \mathrm{mol})$ liberated per $\mu \mathrm{g}$ of total soluble protein (TSP) per minute.

\subsection{Statistical Analysis}

Glyphosate dose-response, and EPSPS enzyme activity data were analyzed using a log-logistic model [23].

$$
Y=\frac{d-c}{1+\exp [b(\log (t)-\log (e))]}
$$

where $Y$ is the response that represents the percent fresh biomass of untreated control or EPSPS enzyme inhibition relative to the control treatment; and $c$ and $d$ are regression parameters representing the equation's lower and upper asymptotes, respectively. Parameter $e$ is the glyphosate rate dose providing $50 \%$ reduction in fresh biomass $\left(\mathrm{GR}_{50}\right)$ or inhibition of EPSPS enzyme activity ( $\left.\mathrm{I}_{50}\right)$ (midway between the $d$, and $c$ parameters), $b$ denotes the slope of the curve around parameter $e$. The model was tested with lack of fit test $(p>0.05)$. If the lower parameter value $(c)$ was equal to zero, the four-parameter equation was reduced to a three-parameter equation:

$$
Y=\frac{d}{1+\exp [b(\log (t)-\log (e))]}
$$

Non-linear regressions were performed using $\mathrm{R}$ version 3.6.1 (R Foundation for Statistical Computing, Vienna, Austria), with drc package [24]. The species were compared in terms of the parameter $e\left(\mathrm{GR}_{50}\right)$ using post hoc $t$-tests. Tolerance index (TI) was calculated as $V$. myuros-to- $A$. spica-venti $\mathrm{GR}_{50}$ ratios to compare the responses from a population of $V$. myuros with a meta-population of $A$. spica-venti.

Two-way ANOVA was performed to test differences between $V$. myuros and A. spica-venti, and among studied growth stages with respect to spray retention and accumulation of shikimic acid. Means were compared by Tukey HSD test at $p<0.05$. Assumption of normality and homogeneous variance were visually examined. Data analysis was performed using R version 3.6.1 (R Foundation for Statistical Computing, Vienna, Austria).

\section{Results}

\subsection{Dose-Response and Spray Retention Study}

\subsubsection{Dose-Response Assay}

The estimated $\mathrm{GR}_{50}$ values showed that $V$. myuros was less susceptible to glyphosate than $A$. spica-venti at all growth stages studied (Figure 1; Table 2). The tolerance index (TI), i.e., $\mathrm{GR}_{50}$ of $V$. myuros relative to $\mathrm{GR}_{50}$ of $A$. spica-venti indicated that $V$. myuros required 2.8, 2.0 and 4.0 times higher doses than $A$. spica-venti for a $50 \%$ reduction of biomass at $\mathrm{BBCH} 11$, $\mathrm{BBCH} 13$ and $\mathrm{BBCH} 21$, respectively in Experiment 1. TI's were between 1.3 and 5.4 in Experiments 2 and 3 (Table 2). The TI was not influenced by the plant growth stage studied 
but plant growth stage had effect on glyphosate effectiveness. For $V$. myuros the significant effect of plant growth stage on glyphosate activity was noticed only in Experiment 1, where the estimated $\mathrm{GR}_{50}$ value was 1.8 and 1.5 fold lower at $\mathrm{BBCH} 13$ and $\mathrm{BBCH} 21$, respectively compared to BBCH 11 (Table 2). Generally, glyphosate activity on A. spica-venti was higher at more advanced than at earlier growth stages in all three experiments $(\mathrm{BBCH} 13$ and BBCH 21 than BBCH 11 in Experiment 1; BBCH 23 compared to BBCH 22 in Experiment 2; and $\mathrm{BBCH} 26$ and $\mathrm{BBCH} 29$ compared BBCH 23 in Experiment 3) (Table 2).
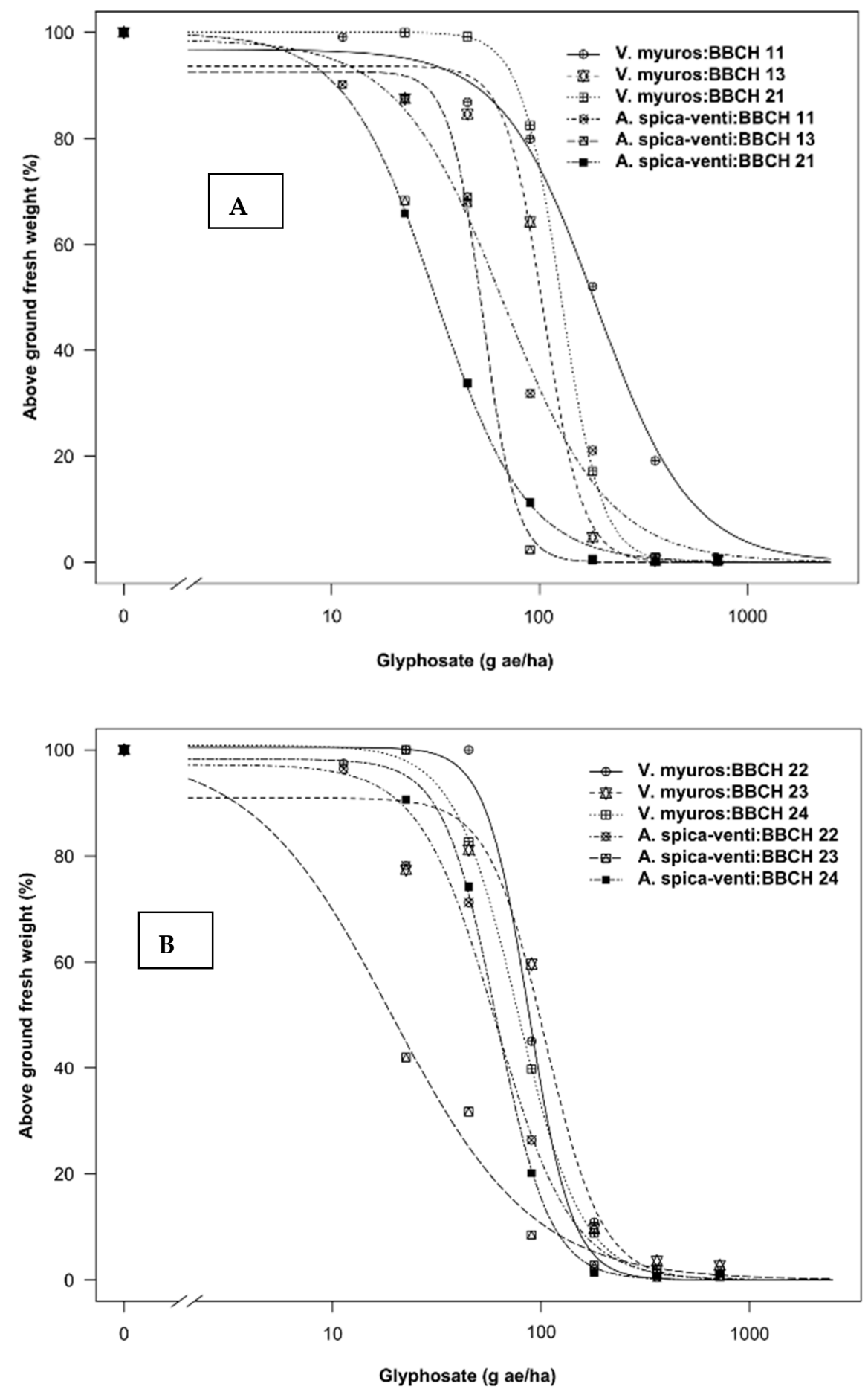

Figure 1. Cont. 


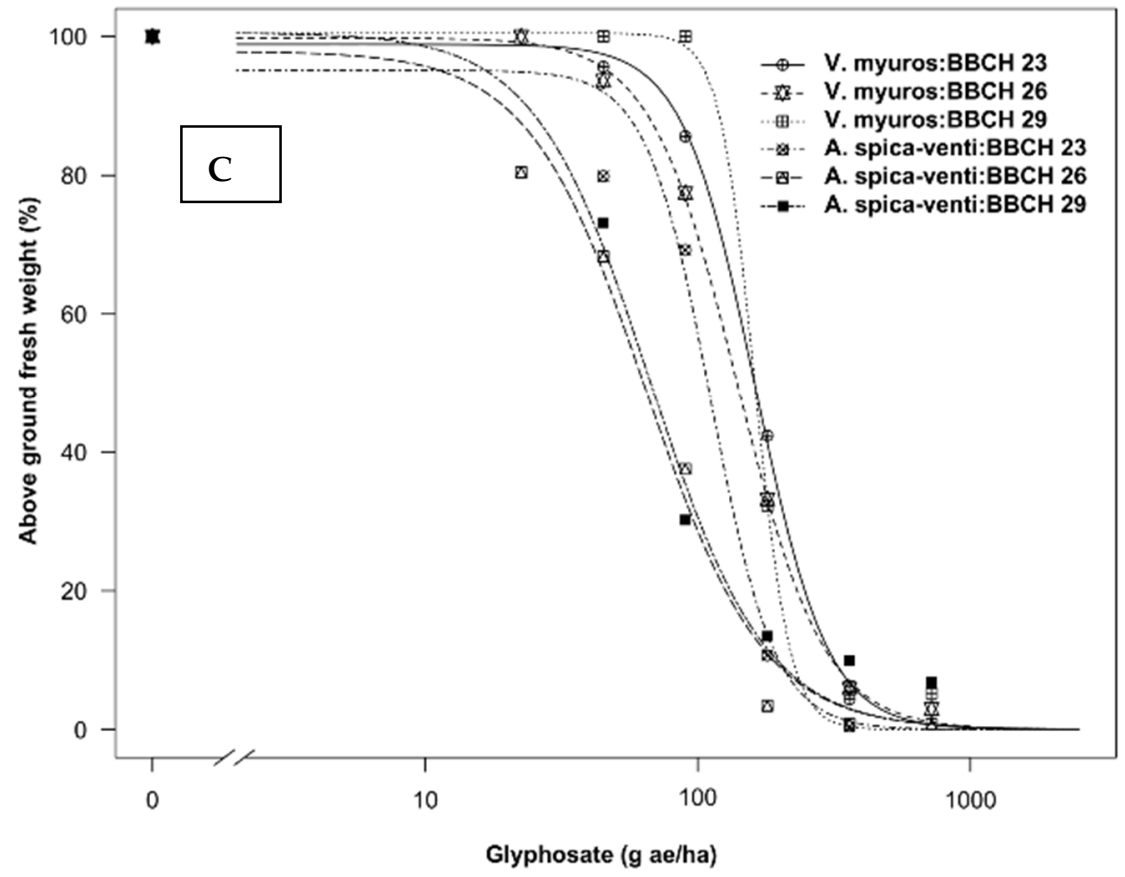

Figure 1. Glyphosate dose-response bio-assay on above-ground fresh weight represented as percentage of untreated control of Vulpia myuros and Apera spica-venti in Experiment 1 (A) Experiment 2 (B) and Experiment $3(\mathbf{C})$.

Table 2. Glyphosate doses (g a.i. ha ${ }^{-1}$ ) providing $50 \%$ reduction in fresh weight $\left(\mathrm{GR}_{50}\right)$ of Vulpia myuros and Apera spica-venti estimated using log-logistic Equations (1) or (2). Standard errors are presented in the parenthesis.

\begin{tabular}{|c|c|c|c|c|}
\hline & \multirow[b]{2}{*}{ Species } & \multicolumn{3}{|c|}{ Growth Stage } \\
\hline & & ВВСН 11 & ВВСН 13 & ВВСН 21 \\
\hline \multirow[t]{2}{*}{ Experiment 1} & V. myuros & $188(25.2)$ & 105 (11.5) & $127(10.3)$ \\
\hline & A. spica-venti & $67(10.0)$ & $53(6.2)$ & $32(3.9)$ \\
\hline Tolerance indices & TI ( $p$ value) & $2.8(p=0.002)$ & $2.0(p=0.003)$ & $4.0(p<0.001)$ \\
\hline Growth stages & Species & BBCH 22 & BBCH 23 & BBCH 24 \\
\hline \multirow[t]{2}{*}{ Experiment 2} & V. myuros & $88(4.6)$ & 105 (12.8) & $78(4.7)$ \\
\hline & A. spica-venti & $61(5.6)$ & $19(5.8)$ & $61(3.5)$ \\
\hline Tolerance indices & TI ( $p$ value) & $1.4(p=0.006)$ & $5.4(p=0.016)$ & $1.3(p=0.015)$ \\
\hline Growth stages & Species & BBCH 23 & BBCH 26 & ВBCH 29 \\
\hline \multirow[t]{2}{*}{ Experiment 3} & V. myuros & $\begin{array}{c}163(13.1) \\
1\end{array}$ & $\begin{array}{c}140(10.4) \\
2\end{array}$ & $\begin{array}{c}165(38.6) \\
3\end{array}$ \\
\hline & A. spica-venti & $111(8.9)$ & $65(6.5)$ & $61(2.3)$ \\
\hline Tolerance indices $b$ & TI ( $p$ value) & $1.4(p=0.0099)$ & $2.16(p<0.001)$ & $2.72(p=0.011)$ \\
\hline
\end{tabular}

Values in the table are $G R_{50}$, representing the glyphosate required providing $50 \%$ reduction in fresh biomass. ${ }^{\mathrm{b}}$ Tolerance index was compared by t-tests at the $5 \%$ level of significance between Vulpia myuros and Apera spica-venti.

\subsubsection{Spray Retention Assay}

There was no treatment-by-experiment interaction between the two glasshouse experiments. Therefore, data from the glasshouse studies were pooled and presented together (Figure 2), while the results from the experiment conducted outdoors are presented separately. Spray deposition was significantly higher on V. myuros compared to A. spica-venti at all growth stages. For instance, in the glasshouse experiment spray deposition was 
3.6, 6.4 and 5.5 times higher on V. myuros than on A. spica-venti at $\mathrm{BBCH} 11, \mathrm{BBCH} 13$ and $\mathrm{BBCH} 21$, respectively. Under outdoor conditions, spray retention was 3.6, 2.3 and 2.0 times higher on V. myuros compared to A. spica-venti at $\mathrm{BBCH} 22, \mathrm{BBCH} 23$ and $\mathrm{BBCH}$ 24 stage, respectively.
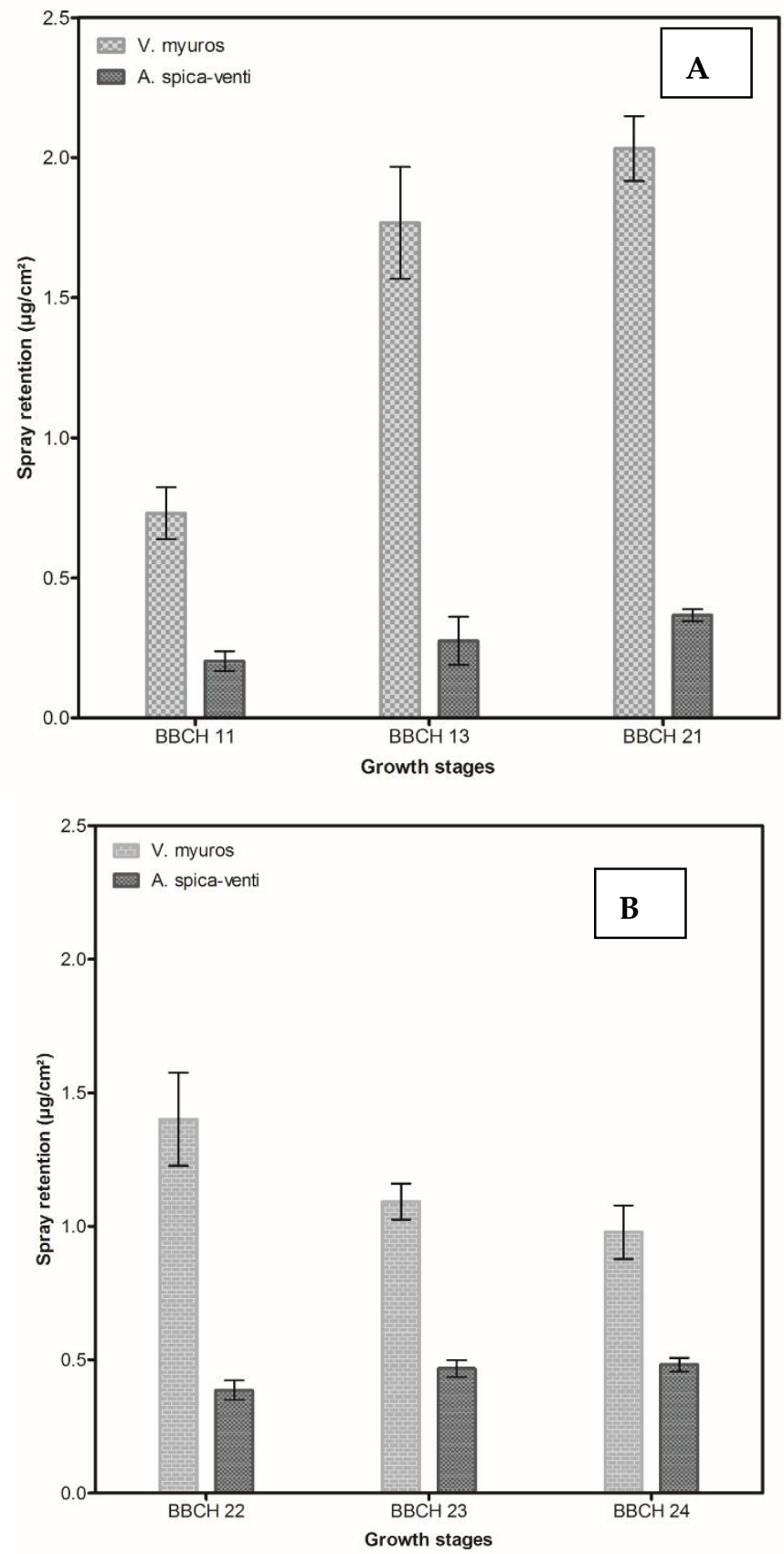

Figure 2. Retention of the glyphosate spray solution on Vulpia myuros and Apera spica-venti in glasshouse (A) and outdoor natural conditions (B). Data from two glasshouse experiments are pooled in figure (A).

Plant growth stage also had a significant effect on spray deposition. For instance, in the glasshouse study (Experiments 1 and 2) spray retention on V. myuros at $\mathrm{BBCH} 11$ stage was significantly lower than at $\mathrm{BBCH} 13$ and $\mathrm{BBCH} 21$, which may explain the lower susceptibility at $\mathrm{BBCH} 11$ compared to the later growth stages (Table 2). A similar trend was observed on A. spica-venti; however, significant differences were only detected between $\mathrm{BBCH} 11$ and $\mathrm{BBCH} 21$. In contrast, under outdoor conditions (Experiment 3) spray 
retention on $V$. myuros tended to decline with increasing growth stages. For example, the spray retention was significantly higher at $\mathrm{BBCH} 22$ stage than at $\mathrm{BBCH} 23$ and $\mathrm{BBCH} 24$, while no difference was observed between BBCH 23 and 24 .

\subsection{Shikimic Acid Accumulation Assays}

In the whole plant assay, the shikimate concentration in plant tissue of $V$. myuros and A. spica-venti increased over time after glyphosate application. The increase in shikimate concentration was significantly higher in A. spica-venti than in V. myuros. At $96 \mathrm{~h}$ after glyphosate application, A. spica-venti accumulated approximately 3 and 5 times more shikimic acid than V. myuros following treatment with 210 and $420 \mathrm{~g} \mathrm{ha}^{-1}$ (Figure 3).

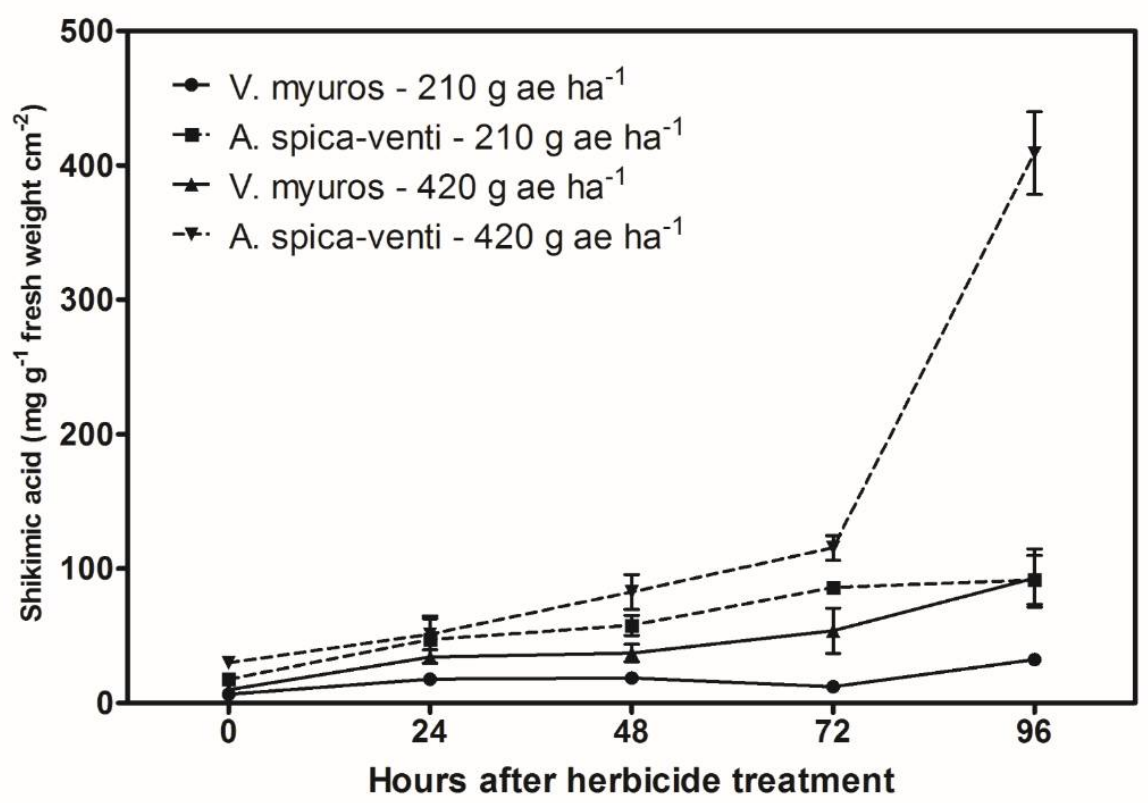

Figure 3. Accumulation of shikimic acid in leaves of Vulpia myuros and Apera spica-venti following treatment with glyphosate (210 and $410 \mathrm{~g}_{\text {ae }} \mathrm{ha}^{-1}$ ). Vertical bars are presenting standard errors of the means.

Similar findings were observed in the assay using leaf segments (Figure 4). At low glyphosate concentrations ( 0.1 and $0.5 \mu \mathrm{mol})$, shikimate accumulation in $V$. myuros and A. spica-venti was similar but with increasing glyphosate concentration shikimate accumulation was higher in A. spica-venti than in V. myuros. Depending on glyphosate concentration, $V$. myuros accumulated 1.2-2.5 fold less shikimate than A. spica-venti. Findings from both the whole plant and leaf-segment shikimic acid bioassays were consistent and showed that the susceptible $A$. spica-venti accumulates more shikimic acid than the tolerant $V$. myuros when exposed to glyphosate.

\subsection{EPSPS Enzyme Sensitivity}

A log-logistic equation was fitted to the EPSPS enzyme activity data for V. myuros, and A. spica-venti, and regression parameters were estimated (Figure 5; Table 3). The regression parameter values for the slope $(b)$, and lower asymptote $(c)$ were not significantly different between the two species studied. In contrast, a comparison of the estimates for the upper asymptote $(d)$, reflecting EPSPS enzyme activity in the absence of glyphosate (baseline activity) revealed a significant difference between the two species $(p<0.001)$. EPSPS baseline activity for $V$. myuros was 1.3 fold higher than for $A$. spica-venti. The glyphosate rates needed to inhibit EPSPS enzyme activity by $50 \%$ ( $\left.\mathrm{I}_{50}\right)$ were $264 \pm 190 \mu \mathrm{M}$ and $81 \pm 75 \mu \mathrm{M}$ for $V$. myuros and A. spica-venti, respectively $(p=0.56)$ (Table 3$)$. 


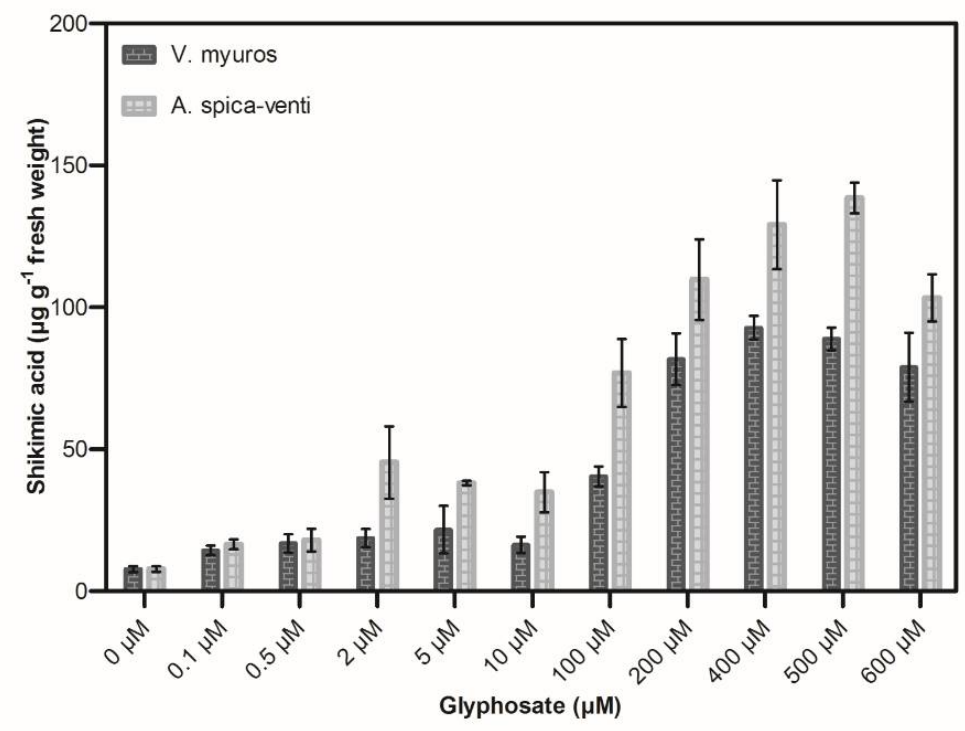

Figure 4. Shikimic acid accumulation in the leaf segment of plants from Vulpia myuros and Apera spica-venti following incubation with different concentrations of glyphosate. Vertical bars represent standard errors of the means.

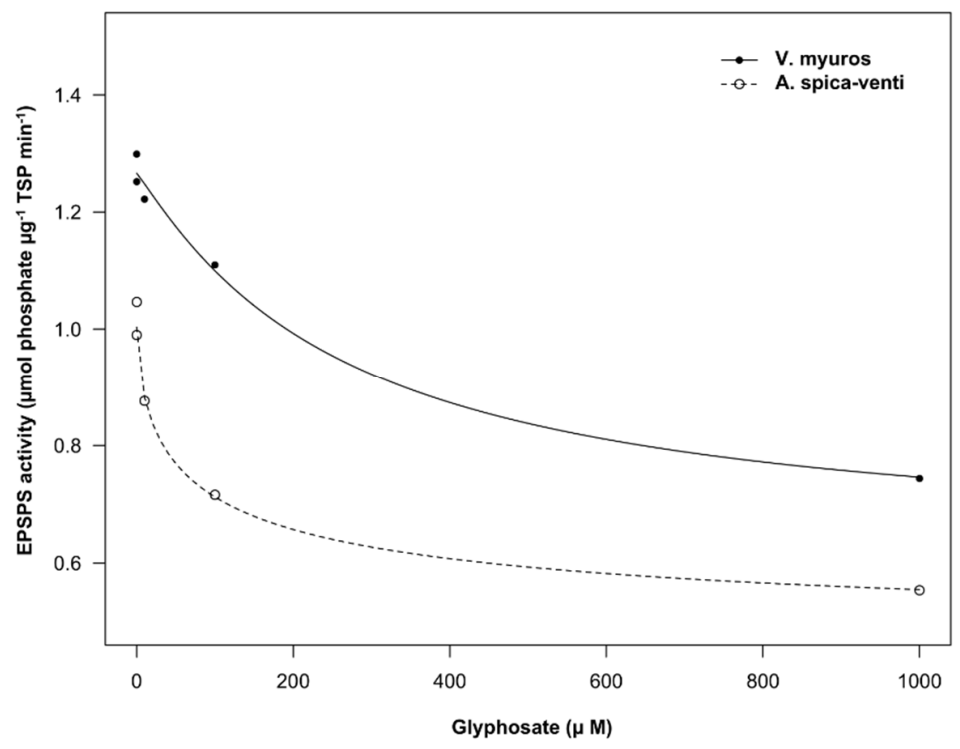

Figure 5. EPSPS activity of Vulpia myuros and Apera spica-venti exposed to different concentrations of glyphosate.

Table 3. Parameter estimates of log-logistic equations (1 or 2) applied to determine the sensitivity of EPSPS enzyme activity to glyphosate in leaf extracts of Vulpia myuros and Apera spica-venti. Standard errors are presented in the parenthesis.

\begin{tabular}{|c|c|c|c|c|}
\hline \multirow[b]{2}{*}{ Species } & \multicolumn{4}{|c|}{ Regression Parameter Estimates ${ }^{a}$} \\
\hline & $b$ & $\begin{array}{c}c \\
\left(\mu \mathrm{mol} \text { phosphate } \mu \mathrm{g}^{-1} \mathrm{TSP}_{\mathrm{min}^{-1}} \text { ) }\right.\end{array}$ & $\frac{d}{\left(\mu \mathrm{mol} \text { phosphate } \mu \mathrm{g}^{-1} \mathrm{TSP} \min ^{-1}\right)}$ & $\begin{array}{l}\mathrm{I}_{50} \\
(\mu \mathrm{M})\end{array}$ \\
\hline Vulpia myuros & $1.1(0.51)$ & $0.6(0.18)$ & $1.3(0.01)$ & $264.0(191)$ \\
\hline Apera spica-venti & $0.6(0.21)$ & $0.4(0.11)$ & $1.0(0.02)$ & $81.1(75.8)$ \\
\hline Significance level $^{b}$ & $p=0.3957$ & $p=0.444$ & $p<0.001$ & $p=0.3834$ \\
\hline
\end{tabular}

${ }^{\mathrm{a}} \mathrm{Y}=d-c /\left(1+\exp \left[b\left(\log (\mathrm{t})-\log \left(I_{50}\right)\right)\right]\right)$. $\mathrm{Y}$ represent the EPSPS inhibition relative to the control treatment, $c$ and $d$ are regression parameters representing the equation's lower and upper asymptotes, respectively. $I_{50}$ is the glyphosate required providing $50 \%$ inhibition of EPSPS enzyme. ${ }^{b}$ Parameter estimates of non-linear regression (Equations (1) or (2)) were compared by $\mathrm{t}$-tests at the $5 \%$ level of significance between Vulpia myuros and Apera spica-venti. 


\section{Discussion}

V. myuros management strategies in no-till systems primarily relies on pre-sowing glyphosate applications [4]. Farmers have reported that glyphosate is only marginally effective in controlling $V$. myuros, in contrast to other grass weeds, such as A. spica-venti. Among scientists and advisors, it is often assumed that ineffective control of $V$. myuros with glyphosate can be attributed to low spray retention due to its narrow and erect leaves $[4,10,11]$. To elucidate the cause(s) of the higher tolerance of $V$. myuros to glyphosate in comparison to other common winter annual grass weed species, we conducted a series of studies on a $V$. myuros population that has never been exposed to glyphosate and compared the responses to a those of a meta-population of A. spica-venti.

\subsection{Dose-Response and Spray Retention Study}

\subsubsection{Dose-Response Study}

Results obtained in dose-response studies showed that the $\mathrm{GR}_{50}$ values for $V$. myuros were 2 to 3 times higher than for A. spica-venti, irrespective of growth stage (Figure S1). However, the actual doses needed to control the two grass weed species were lower than the recommended field doses, which illustrates that pot-grown grass weeds are generally more susceptible than plants in the field. Interestingly, V. myuros susceptibility to glyphosate was consistently lower than $A$. spica-venti in three experiments. Field studies have shown that glyphosate is not highly effective in controlling $V$. myuros and that the doses needed for satisfactory control are often higher than the recommended doses [20,25]. Yu et al. [17] studying the closely related species V. bromoides, proved its tolerance to ACCase and several ALS inhibitors and concluded that an insensitive ACCase and enhanced metabolism were the likely mechanisms of tolerance to the two modes of action. Hull et al. [3] confirmed that $V$. myuros was tolerant to the two herbicide groups. Here, we report for the first time that $V$. myuros is also tolerant to glyphosate.

\subsubsection{Spray Retention Study}

Previous studies have shown that variation in plant architecture and leaf characteristics can contribute to differences in herbicide deposition on treated plants [26,27]. In V. myuros, the presence of several pubescent veins on the leaf surface and rough leaf margins may result in a higher herbicide retention than on the light and hairless leaves of A. spica-venti [28,29]. Differences in the chemical composition and/or structure of the cuticle could also influence spray retention [30]. In contrast to many studies relating the poor performance of glyphosate on $V$. myuros to low spay retention $[4,10,11,19]$, this study showed that reduced spray retention is not the cause of the low performance of glyphosate on V. myuros.

In the current study, no correlation was found between spray deposition and herbicide efficacy on the two grass weed species. In contrast, a close relationship was found between glyphosate activity and spray retention comparing growth stages of the same species. For instance, in Experiment 1,V. myuros control with glyphosate was low if sprayed at the early plant growth stage (BBCH 11) while control was higher when sprayed at later growth stages (BBCH 13 and $\mathrm{BBCH} 21$ ), and a similar trend was observed for A. spica-venti in three experiments. Overall, our results are in line with those previously reported for $V$. myuros, and other grass weeds in the literature $[11,31,32]$. In contrast to dicot weeds, grass weeds, due to lower spray retention on the more erect leaves, are generally less susceptible to foliar applied herbicides at very early growth stages than at later growth stages [32]. Ball et al. [11] suggested that the erect leaf orientation of young $V$. myuros seedlings are limiting spray coverage on the leaf surface. The higher retention at later growth stages resulted in a better control than at earlier growth stages in Experiments 1 and 2 (Figure 2; Table 2). Similar to our findings, Koo et al. [33] also found a close relationship between foliar retention of pyribenzoxim and its activity on Echinochloa crus-galli.

It can be argued that dose-response and spray retention experiments were carried out at different growth stages and under different growing conditions, but it is important 
to emphasize here that the primary aim of these experiments was to study the level and causes(s) of $V$. myuros tolerance to glyphosate. $V$. myuros susceptibility to glyphosate was lower than of $A$. spica-venti, and the reason of low susceptibility to glyphosate in $V$. myuros was not caused by lower retention, as previously suggested. Interestingly, these results were consistent across experiments that were carried out at different growth stages and growing conditions.

\subsection{Shikimic Acid Accumulation Assays}

Inhibition of the EPSPS enzyme is the mechanism of glyphosate action in plants, which results in the accumulation of shikimic acid in glyphosate sensitive weed plants [15,34]. Shikimate accumulation and EPSPS enzyme activity analysis are considered appropriate parameters to determine tolerance to glyphosate [13]. The findings from the whole plant and leaf-segment shikimic acid bioassays suggest that glyphosate incurs lower inhibition of EPSPS in V. myuros than in A. spica-venti. The somewhat smaller difference between the two plant species using leaf segments, compared to whole plants, is likely due to the fact that the exposure to glyphosate was the same in contrast to the whole plant assay, where more glyphosate was retained on the $V$. myuros than on the $A$. spica-vent $i$ plants. The presence of $200 \mu \mathrm{M}$ or more of glyphosate did not significantly increase the accumulation of shikimic acid in $V$. myuros. In contrast, in the case of $A$. spica-venti, there was a significant increase in the accumulation of shikimic acid even at concentration of $500 \mu \mathrm{M}$. In glyphosate-resistant species, the lower accumulation of shikimic acid can be explained by either a functional feedback control mechanism of the shikimic pathway by the precursor that regulates the 3-deoxy-d-arabino-heptulosonate-7-phosphate (DAHP) synthase activity, and/or a lower interaction with the EPSPS enzyme by glyphosate [35]. The former mechanism prevents further accumulation of shikimic acid and limits the reaction rate early in the pathway, and this scenario can explain the results observed in the leaf-segment shikimic acid bioassays. In vitro methods measuring shikimic acid accumulation have been widely used for detecting glyphosate resistance in plants, where leaf segments are immersed in a glyphosate medium and then incubated [36]. This method has proven to be an effective and quick way to evaluate the differences among glyphosate-resistant and susceptible plants [37]. In our study, the whole plant shikimic acid assay also provided evidence that the interaction of glyphosate with EPSPS was lower in V. myuros than in A. spica-venti.

\subsection{EPSPS Enzyme Sensitivity}

Several studies reported high activity of EPSPS as a mechanism of glyphosate resistance $[15,34,38]$. The larger concentration of EPSPS enzyme in the total protein extracted from sample tissue as a whole/or per unit fresh weight limits glyphosate activity and prevents blocking of the shikimic pathway. Previous studies reported a strong relation between baseline EPSPS enzyme activity and gene copy number [34,39]. Higher baseline EPSPS activity could contribute to V. myuros tolerance to glyphosate. Although results from the current study have shown an association between glyphosate tolerance and higher EPSPS enzyme activity in V. myuros, it remains to be understood why the higher spray deposition on $V$. myuros did not overcome the effect of the difference in EPSPS activity.

Genome duplication might contribute to gene multiplication, which can lead to the evolution of genes with modified functions [34,40]. The presence of multiple genomes (polyploidy) can provide novel traits to plants [40,41]. For instance, Bunnell et al. [42] has reported that tetraploid individuals of bahiagrass (Paspalum notatum) were tolerant to metsulfuron while diploid individuals were susceptible. It is possible that a higher baseline EPSPS activity could be attributed to the higher genome size of the hexaploid $V$. myuros $(2 n=42)$ with potentially multiple functional EPSPS alleles compared to the diploid $A$. spica-venti $(2 n=14)$. Our study measured the EPSPS enzyme activity at several glyphosate doses in order to determine if a target-site mechanism may have caused the low sensitivity of $V$. myuros [34]. The $\mathrm{I}_{50}$ values for $A$. spica-venti were lower but not statistically different from $V$. myuros (Table 3), indicating that EPSPS from $V$. myuros is as susceptible 
to glyphosate as EPSPS from A. spica-venti suggesting no alternation in the binding site of EPSPS [15]. According to Salas et al. [34] the amino acids present in the catalytic site of EPSPS are very conserved, hence, target-site mutation in plants from natural populations is very rare compared to other herbicide target sites. As there is no evidence of differences in susceptibility within populations of $V$. myuros to glyphosate (Kudsk, pers. comm.), it is very unlikely that any selection for higher EPSPS activity has occurred in natural populations of this species. This assumption is further supported by the fact that $V$. myuros is a new weed species that has been intensively exposed to glyphosate for only a few years. Hence, we suggest that the higher level of EPSPS activity is an intrinsic property of $V$. myuros that might be due to the higher ploidy level, and it is less likely that any resistance mechanisms, such as target-site mutation or reduced absorption, translocation, metabolism and vacuolar sequestration, is the cause of low glyphosate susceptibility in $V$. myuros.

\section{Conclusions}

The current study confirmed that $V$. myuros is more tolerant than other grass species to glyphosate as it is to other herbicide modes of action and it showed that the tolerance is not attributed to low spray retention as previously anticipated. The EPSPS activity in $V$. myuros was elevated compared to A. spica-venti and could explain the lower accumulation of shikimic acid in $V$. myuros and the observed difference in the susceptibility between the two grass weed species. Despite innate tolerance of V. myuros to glyphosate, the relative difference in the accumulation of shikimic acid and the estimated $\mathrm{GR}_{50}$ values between the two species suggest that $V$. myuros can be controlled by glyphosate but its susceptibility is lower compared to other grass weeds, such as A. spica-venti. Because of its tolerance to many selective graminicides, the chemical control of $V$. myuros largely depends on glyphosate. Overuse of glyphosate, due to a lack of other chemical options, may trigger the evolution of resistance to glyphosate in V. myuros. To avoid this, the use of glyphosate should be combined with other control strategies, such as a diversified crop rotation and cultivation where possible [42,43].

Supplementary Materials: The following are available online at https:/ /www.mdpi.com/article/ 10.3390/agriculture11080725/s1, Figure S1: Photographic representation of dose-response for the tolerant Vulpia myuros and susceptible Apera spica-venti.

Author Contributions: Conceptualization, P.K., M.J.A., S.K.M., Z.E.B., H.B.-P.; methodology, M.J.A., Z.E.B.; writing-original draft, M.J.A.; review and editing, P.K., S.K.M., M.J.A., Z.E.B., H.B.-P.; formal analysis, M.J.A.; supervision, P.K. and S.K.M.; project administration, P.K.; funding acquisition, P.K. All authors have read and agreed to the published version of the manuscript.

Funding: Muhammad Javaid Akhter was partially funded by the Graduate School of Science and Technology, Aarhus University, as part of his Ph. D. study, and partially funded by the European Union's Horizon 2020 research and innovation program, under grant agreement No. 727321 (IWMPRAISE).

Institutional Review Board Statement: Not applicable.

Informed Consent Statement: Not applicable.

Data Availability Statement: Not applicable.

Acknowledgments: We acknowledge Christian Nielsen, Betina Bendtsen and Bente Laursen and for their skillful technical assistance.

Conflicts of Interest: The authors declare no conflict of interest.

\section{References}

1. Akhter, M.J. Biology and Management of Vulpia Myuros in Arable Farming. Ph.D. Thesis, Aarhus University, Aarhus, Denmark, 16 December 2020.

2. Mathiassen, S.K.; Henriksen, K.E. Experience on Vulpia myuros in Denmark-biology, seed survival, herbicide efficacy and selectivity. In Proceedings of the Tagungsunterlagen, 51. Fachtagung des DLG-Ausschusses “Gräser, Klee und Zwischenfrüchte", Bonn, Germany, 5 November 2010; Susanne, S., Ed.; Fachzeentrum Land-und Ernahrungswirtschaft Eschboorner Landstrabe 122: Frankfurt am Main, Germany, 2010. 
3. Hull, R.; Mathiassen, S.K.; Moss, S.R. Herbicidal control of Vulpia myuros (Rat's-tail fescue) in glasshouse screening tests. Asp. Appl. Biol. 2011, 106, 75-81.

4. Akhter, M.J.; Jensen, P.K.; Mathiassen, S.K.; Melander, B.; Kudsk, P. Biology and Management of Vulpia myuros-An Emerging Weed Problem in No-Till Cropping Systems in Europe. Plants 2020, 9, 715. [CrossRef] [PubMed]

5. Javaid Akhter, M.; Melander, B.; Mathiassen, S.K.; Labouriau, R.; Vendelbo Nielsen, S.; Kudsk, P. Growth and Phenology of Vulpia Myuros in Comparison with Apera spica-venti, Alopecurus Myosuroides and Lolium Multiflorum in Monoculture and in Winter Wheat. Plants 2020, 9, 1495. [CrossRef] [PubMed]

6. Ball, D.A.; Frost, S.M.; Fandrich, L.; Tarasoff, C.; Mallory-Smith, C. Biological Attributes of Rattail Fescue (Vulpia myuros). Weed Sci. 2008, 56, 26-31. [CrossRef]

7. Akhter, M.J.; Kudsk, P.; Mathiassen, S.K.; Melander, B. Rattail fescue (Vulpia myuros) interference and seed production as affected by sowing time and crop density in winter wheat. Weed Sci. 2021, 69, 52-61. [CrossRef]

8. Scherner, A.; Melander, B.; Kudsk, P. Vertical distribution and composition of weed seeds within the plough layer after eleven years of contrasting crop rotation and tillage schemes. Soil Tillage Res. 2016, 161, 135-142. [CrossRef]

9. Kudsk, P.; Mathiassen, S.K. Pesticide regulation in the European Union and the glyphosate controversy. Weed Sci. 2020, 68, 214-222. [CrossRef]

10. Bowran, D.; Wallace, A. Chemical weed management of Vulpia. Plant Prot. Q. 1996, 11, 211-212.

11. Ball, D.A.; Hulting, A.G.; Lyon, D.J. Rattail Fescue: Biology and Management in Pacific Northwest Wheat Cropping Systems. 2018. Available online: https:/ / pubs.extension.wsu.edu/rattail-fescue-biology-and-management-in-pacific-northwest-wheatcropping-systems (accessed on 4 June 2020).

12. Steinrücken, H.C.; Amrhein, N. The herbicide glyphosate is a potent inhibitor of 5-enolpyruvylshikimic acid-3-phosphate synthase. Biochem. Biophys. Res. Commun. 1980, 94, 1207-1212. [CrossRef]

13. Dayan, F.E.; Owens, D.K.; Corniani, N.; Silva, F.M.L.; Watson, S.B.; Howell, J.L.; Shaner, D.L. Biochemical markers and enzyme assays for herbicide mode of action and resistance studies. Weed Sci. 2015, 63, 23-63. [CrossRef]

14. Sammons, R.D.; Gaines, T.A. Glyphosate resistance: State of knowledge. Pest Manag. Sci. 2014, 70, 1367-1377. [CrossRef]

15. Gaines, T.A.; Zhang, W.; Wang, D.; Bukun, B.; Chisholm, S.T.; Shaner, D.L.; Nissen, S.J.; Patzoldt, W.L.; Tranel, P.J.; Culpepper, A.S. Gene amplification confers glyphosate resistance in Amaranthus palmeri. Proc. Natl. Acad. Sci. USA 2010, 107, 1029-1034. [CrossRef]

16. Moretti, M.L.; Van Horn, C.R.; Robertson, R.; Segobye, K.; Weller, S.C.; Young, B.G.; Johnson, W.G.; Douglas Sammons, R.; Wang, D.; Ge, X. Glyphosate resistance in Ambrosia trifida: Part 2. Rapid response physiology and non-target-site resistance. Pest Manag. Sci. 2018, 74, 1079-1088. [CrossRef]

17. Yu, Q.; Shane Friesen, L.J.; Zhang, X.Q.; Powles, S.B. Tolerance to acetolactate synthase and acetyl-coenzyme A carboxylase inhibiting herbicides in Vulpia bromoides is conferred by two co-existing resistance mechanisms. Pestic. Biochem. Physiol. 2004, 78, 21-30. [CrossRef]

18. Schroeder, J. Minutes of the WSSA Board of Directors Meeting Chicago, IL February 12, 1998. Weed Sci. 1998, 46, 628-630. [CrossRef]

19. Crease, G.J.; Hall, F.R.; Thacker, J.R.M. Reflection of agricultural sprays from leaf surfaces. J. Environ. Sci. Health B 1991, 26, 383-407. [CrossRef]

20. Ball, D.A.; Frost, S.M.; Bennett, L.H.; Thill, D.C.; Rauch, T.; Jemmett, E.; Mallory-Smith, C.; Cole, C.; Yenish, J.P.; Rood, R. Control of rattail fescue (Vulpia myuros) in winter wheat. Weed Technol. 2007, 21, 583-590. [CrossRef]

21. Babineau, M.; Mathiassen, S.K.; Kristensen, M.; Kudsk, P. Fitness of ALS-Inhibitors Herbicide Resistant Population of Loose Silky Bentgrass (Apera spica-venti). Front. Plant Sci. 2017, 8, 1660. [CrossRef] [PubMed]

22. Singh, B.K.; Shaner, D.L. Rapid determination of glyphosate injury to plants and identification of glyphosate-resistant plants. Weed Technol. 1998, 12, 527-530. [CrossRef]

23. Ritz, C.; Baty, F.; Streibig, J.C.; Gerhard, D. Dose-response analysis using R. PLoS ONE 2015, 10, e146021. [CrossRef] [PubMed]

24. Ritz, C.; Streibig, J.C. Bioassay analysis using R. J. Stat. Softw. 2005, 12. [CrossRef]

25. Jemmett, E.D.; Thill, D.C.; Rauch, T.A.; Ball, D.A.; Frost, S.M.; Bennett, L.H.; Yenish, J.P.; Rood, R.J. Rattail fescue (Vulpia myuros) control in chemical-fallow cropping systems. Weed Technol. 2008, 22, 435-441. [CrossRef]

26. Michitte, P.; De Prado, R.; Espinoza, N.; Ruiz-Santaella, J.P.; Gauvrit, C. Mechanisms of resistance to glyphosate in a ryegrass (Lolium multiflorum) biotype from Chile. Weed Sci. 2007, 55, 435-440. [CrossRef]

27. Pérez-López, M.; González-Torralva, F.; Cruz-Hipólito, H.; Santos, F.; Domínguez-Valenzuela, J.A.; De Prado, R. Characterization of glyphosate-resistant tropical sprangletop (Leptochloa virgata) and its alternative chemical control in Persian lime orchards in Mexico. Weed Sci. 2014, 62, 441-450. [CrossRef]

28. Wallace, A. The biology of Australian weeds. 30. Vulpia bromoides ((L.) SF Gray) and V. myuros ((L.) CC Gmelin). Plant Prot. Q. 1997, 12, 18-28.

29. Warwick, S.I.; Black, L.D.; Zilkey, B.F. Biology of canadian weeds: 72. Apera spica-venti. Can. J. Plant Sci. 1985, 65, 711-721. [CrossRef]

30. Holloway, P.J. Physicochemical factors influencing the adjuvant-enhanced spray deposition and coverage of foliage-applied agrochemicals. In Interactions between Adjuvants, Agrochemicals and Target Organisms; Springer: Berlin/Heidelberg, Germany, 1994; pp. 83-106.

31. Mathiassen, S.K. XI Effects of new adjuvants, N32 and pH of the spray solution on herbicide efficacy. Appl. Crop Protec. 2016, 94, 119-123. 
32. Powell, E.S.; Orson, J.H.; Miller, P.C.H.; Kudsk, P.; Mathiassen, S.K. Defining the size of target for air induction nozzles. Defining the size of target for air induction nozzles. Asp. Appl. Biol. 2002, 66, 65-72.

33. Koo, S.-J.; Kim, J.-S.; Lee, J.-H. Foliar retention of the herbicide pyribenzoxim (1\% EC), and its effects on herbicidal activity and rice phytotoxicity. Korean J. Weed Sci. 1998, 18, 304-313.

34. Salas, R.A.; Dayan, F.E.; Pan, Z.; Watson, S.B.; Dickson, J.W.; Scott, R.C.; Burgos, N.R. EPSPS gene amplification in glyphosateresistant Italian ryegrass (Lolium perenne ssp. multiflorum) from Arkansas. Pest Manag. Sci. 2012, 68, 1223-1230. [CrossRef] [PubMed]

35. Jensen, R.A. The shikimate/arogenate pathway: Link between carbohydrate metabolism and secondary metabolism. Physiol. Plant. 1986, 66, 164-168. [CrossRef]

36. Zimdahl, R.L. Weed-Crop Competition: A Review; International Plant Protection Center: Corvallis, OR, USA, 1980.

37. Perez-Jones, A.; Park, K.W.; Colquhoun, J.; Mallory-Smith, C.; Shaner, D. Identification of glyphosate-resistant Italian ryegrass (Lolium multiflorum) in Oregon. Weed Sci. 2005, 53, 775-779. [CrossRef]

38. Fernández-Moreno, P.T.; Alcántara-de la Cruz, R.; Smeda, R.J.; De Prado, R. Differential resistance mechanisms to glyphosate result in fitness cost for Lolium perenne and L. multiflorum. Front. Plant Sci. 2017, 8, 1796. [CrossRef] [PubMed]

39. Alarcón-Reverte, R.; García, A.; Watson, S.B.; Abdallah, I.; Sabaté, S.; Hernández, M.J.; Dayan, F.E.; Fischer, A.J. Concerted action of target-site mutations and high EPSPS activity in glyphosate-resistant junglerice (Echinochloa colona) from California. Pest Manag. Sci. 2015, 71, 996-1007. [CrossRef] [PubMed]

40. Paterson, A.H.; Kong, W.; Johnston, R.M.; Nabukalu, P.; Wu, G.; Poehlman, W.L.; Goff, V.H.; Isaacs, K.; Lee, T.-H.; Guo, H. The evolution of an invasive plant, Sorghum halepense L. ('Johnsongrass'). Front. Genet. 2020, 11, 317. [CrossRef] [PubMed]

41. Soltis, D.E.; Buggs, R.J.A.; Doyle, J.J.; Soltis, P.S. What we still don't know about polyploidy. Taxon 2010, 59, 1387-1403. [CrossRef]

42. Bunnell, B.T.; Baker, R.D.; McCarty, L.B.; Hall, D.W.; Colvin, D.L. Differential Response of Five Bahiagrass (Paspalum notatum) Cultivars to Metsulfuron1. Weed Technol. 2003, 17, 550-553. [CrossRef]

43. Akhter, M.J.; Abdurruhman, A.M.; Mathiassen, S.K.; Kudsk, P. Low Effectiveness of Prosulfocarb and Mesosulfuron-methyl+ Iodosulfuron-methyl against Vulpia myuros. Plants 2020, 10, 1186. [CrossRef] 